\title{
O INSÓLITO NA FICÇÃO DE B. KUCINSKI
}

Thaís Sant'Anna Marcondes (UFF)

Recebido em 05 jan 2019. Thaís Sant'Anna Marcondes é Doutoranda em Aprovado em 05 jul 2020. Literatura Comparada pela UFF. Mestre em Teoria Literária e Literatura Brasileira pela UFF. A produção bibliográfica mais significativa é um texto constitutivo dos anais do VIII SAPPIL em Estudos de Literatura, intitulado Memória e fragmento em K. Relato de uma busca. Participo do grupo de pesquisa "Nação e narração", coordenado pela prof.a Lucia Helena. As áreas de interesse de pesquisa são história do Brasil, política, ditadura militar, literatura contemporânea.

Lattes: http://lattes.cnpq.br/6097224456269813

E-mail: thaissantannamarcondes@gmail.com

ORCID iD: https://orcid.org/0000-0001-9678-3940

Resumo: Depois do sucesso de $K$. Relato de uma busca, B. Kucinski se aventura no terreno da ficção policial, com seu livro Alice: não mais que de repente. Inserindo elementos textuais característicos do romance detetivesco e diversas referências aos clássicos do gênero, o autor surpreende ao apresentar uma aliança entre um policial ético e íntegro e um cientista cassado pela ditadura militar. A investigação empreendida por esses dois personagens detetives, acompanhados por seus ajudantes, trará como pano de fundo uma análise crítica da universidade no Brasil. Partindo de uma concepção do insólito que abarca não só elementos fantasmagóricos, como também forças que fazem repensar o absurdo e o 
incomum dentro das expectativas da realidade, o presente artigo tem como objetivo fazer um resumo comentado desta obra e apontar para os possíveis elementos insólitos estruturados pela narrativa que compõem um movimento de desestabilização no leitor do início ao fim.

Palavras-chave: B. Kucinski; Insólito; Narrativa Criminal; Universidade; Ciência.

Resumen: Después del éxito de $K$. Relato de uma busca, B. Kucinski se aventura en el terreno de la ficción policial con su libro Alice: não mais que de repente. Al insertar elementos textuales característicos de la novela de detectives y varias referencias a los clásicos del género, el autor sorprende al presentar una alianza entre un oficial de policía ético y justo y un científico perseguido por la dictadura militar. La investigación realizada por estos dos personajes detectivescos, acompañados por sus ayudantes, traerá como contexto una reflexión crítica de la universidad en Brasil. Partiendo de una concepción de lo insólito que abarca no solo elementos sobrenaturales, sino también fuerzas que hacen repensar lo absurdo y lo inusual dentro de las expectativas de la realidad, este artículo tiene como objetivo hacer un resumen comentado de este libro y señalar posibles elementos insólitos estructurados por la narrativa que constituyen un movimiento desestabilizador en el lector de principio a fin.

Palabras clave: B. Kucinski; Insólito; Narrativa Criminal; Universidad; Ciencia

\section{INTRODUÇÃO}

No século XVIII, a Revolução Industrial, que alterou a antiga economia agrária e consolidou o capitalismo, provocou profundas transformações sociais. Com a formação das sedutoras 
metrópoles marcadas pela industrialização, a migração do campo para a cidade foi um fenômeno que apontou para os dois lados da mesma moeda revolucionária: o progresso e a miséria. Os moradores do campo buscavam nas áreas urbanas supostas vantagens, como melhores condições de vida e emprego nas fábricas. Porém, a intensificação do movimento migratório acelerou o crescimento populacional das metrópoles que, despreparadas para abrigar tanta gente de repente, ofereciam, na verdade, condições deploráveis de trabalho, infraestrutura, saneamento e moradia. Esse contexto de desordem e caos acabou gerando segregação social e, como consequência, o aumento da criminalidade. Até esta época, os crimes não eram vistos como algo coletivo, que poderiam caracterizar uma ameaça social, e o sistema que pretendia dar conta de punir quem sofria algum tipo de crime se constituía basicamente de ofertas de recompensas ou da contratação particular de um agente especializado.

É apenas no século XIX que, de acordo com Sandra Lúcia Reimão (1983, p.11), se desenvolverá a polícia na acepção contemporânea do termo e o criminoso passará a ser visto como inimigo social. Nestes dias, ex-condenados eram chamados para atuar como policiais na França. O mais famoso da época, Vidocq, assim como os outros policiais, conhecia com propriedade o mundo dos crimes e os investigava, desvendando os enigmas que Ihe eram apresentados. Vidocq, em 1828, lança seu livro de memórias, em que expõe sua experiência de convivência com os criminosos e suas façanhas como investigador. De acordo com Carla Portilho, a capacidade brilhante deste ex-condenado para conduzir a resolução de crimes influenciou a construção da 
imagem do detetive eficaz que será aproveitada posteriormente pela ficção:

A personalidade de Vidocq e seu sucesso na profissão que criou deram ao público em geral uma clara concepção do 'detetive ideal' - de onde muitos detetives da ficção herdaram suas características, como grande força física, paciência e resistência, talento para o disfarce e uma intuição da mentalidade criminosa, assim como sua reputação de sucesso garantido e momentos dramáticos de triunfo pessoal. (PORTILHO, 2009, p.47)

Porém, passado esse primeiro momento, a população das novas cidades industriais não se mostrará satisfeita com a instituição: "Para as novas, instáveis e perplexas classes médias, era tênue demais o limite entre um contraventor e um ex-contraventor" (REIMÃO, 1983, p.15). A desconfiança e a insatisfação geradas pela instituição influenciarão o plano ficcional. Como consequência, os primeiros famosos detetives da literatura não serão investigadores ligados à polícia.

Ricardo Piglia, em Formas breves, ao analisar o gênero policial, considera o afastamento do detetive de todas as instituições, inclusive a polícia, uma vantagem para a resolução dos crimes, pois ele é a figura responsável por interpretar à sua maneira algo que aconteceu, do qual ficaram alguns sinais, e só pode fazer isso porque não está ligado a nenhuma instituição: “O detetive não pertence ao mundo do delito nem ao mundo da lei; não é um policial e tampouco um criminoso [...], o detetive particular está aí para fazer ver que a lei, em seu lugar institucional, a polícia, funciona mal" (PIGLIA, 2004, p.57). O detetive é um personagem que está fora, 
que não se liga a nenhuma instituição social, e, por essa distância, é capaz de interpretar uma história da qual está à parte, "a verdade que é visível, mas que ninguém viu" (PIGLIA, 2004, p.57).

É o caso do personagem de Edgar Allan Poe, C. Auguste Dupin, um detetive amador que não investiga os casos empiricamente como os policiais ex-condenados. Para Dupin, investigar é um hobby que pratica sem que seja necessário sair de sua residência. Seu raciocínio preenche lacunas e liga os fatos que conhece apenas por ouvir dizer. Outro detetive muito conhecido na literatura que não se liga à polícia é Sherlock Holmes, personagem de Conan Doyle, que, além do raciocínio lógico, usará a seu serviço procedimentos técnicos científicos em suas investigações. Também não se vinculava à polícia o detetive belga Hercule Poirot que ganhou vida nas ficções de Agatha Christie. Esses detetives clássicos da literatura eram sujeitos extraordinários que reuniam indícios e solucionavam casos de forma inteligente e perspicaz. Há, nessas narrativas, certa aversão aos policiais comuns, vistos como incapazes de solucionar de forma brilhante um mistério e de atender às exigências da burguesia.

Fernanda Massi, em O romance policial do século XXI, faz um estudo comparativo entre as narrativas policiais clássicas e as narrativas policiais contemporâneas, e, ao enfocar os personagens principais dos textos estudados, constata que essa imagem do detetive profissional lógico e racional vem perdendo espaço para sujeitos comuns, como funcionários da polícia, por exemplo (MASSI, 2011, p.77). Nestes casos, a investigação não é apenas um hobby, como era para os detetives ficcionais clássicos, ela é uma obrigação, um dever de quem trabalha na polícia. 
Analisando a literatura brasileira especificamente, Pedro Silva (2019, p.430) observa que, em finais do século XIX e ao longo do século $X X$, os protagonistas de nossas narrativas criminais são detetives de polícia. Entretanto, esses personagens não exaltavam a instituição policial, seja porque representavam uma polícia caricata, seja porque apontavam para a instituição como espaço de corrupção, machismo, violência e ineficácia. Se os detetives clássicos da literatura criminal não eram representados por policiais porque a classe dominante não confiava na destreza da polícia para solucionar os casos, no Brasil, a polícia era marcada pela brutalidade e pela falta de preparo, equipamento e salário, o que foi se agravando com o decorrer do tempo. E, apesar de parte da população tomar como heroica a atitude violenta de policiais, a narrativa criminal no Brasil, "longe de elevar a polícia violenta ao status de herói, sempre fez o possível para mostrar o lado negativo desse tipo de prática" (SILVA, 2019, p.433).

Um personagem policial é o responsável pela investigação de um crime em uma universidade de São Paulo. Esta é a situação do delegado Magno, protagonista do livro Alice: não mais que de repente, de B. Kucinski. Magno é um policial íntegro que vai conduzir a investigação com a racionalidade dos detetives clássicos. Ao mesmo tempo, Kucinski não vai deixar de apontar para a violência brutal da instituição.

Depois de publicar quatorze livros sobre política, jornalismo e economia, B. Kucinski, aos 70 anos, deu início ao ofício de escritor de literatura. Seu romance de estreia, K. Relato de uma busca, publicado em 2011, teve uma excelente recepção crítica no Brasil e também obteve sucesso no exterior, com traduções 
para o alemão, inglês, espanhol, italiano e hebraico. O livro narra a história de um pai em busca da filha desaparecida durante a ditadura militar no Brasil. Em 2014, o autor publicou a coletânea Você vai voltar pra mim e outros contos, composto por narrativas curtas que apresentam personagens que viveram o horror da repressão militar.

Ainda em 2014, o autor se afasta do tema da ditadura militar e publica seu segundo romance, que é o foco deste trabalho, Alice: não mais que de repente. Em uma de suas viagens, em que retornava ao Brasil, vindo de Israel, o autor leu no avião o livro de Batya Gur intitulado Murder in Kibutz. Nele, a autora, a pretexto de elucidar um crime, faz uma sociologia completa do Kibutz, expondo seu histórico, sua decadência e seus conflitos internos. A exemplo da autora, B. Kucinski decide fazer uma crítica severa à universidade onde estudou e lecionou em forma de romance policial, sem a necessidade de provas que corroborem os fatos narrados e sem perder o senso crítico em relação às instituições sociais - característico do autor.

Seu livro de estreia, $K$. Relato de uma busca, apresenta como mote o desaparecimento de uma professora de química da Universidade de São Paulo (USP) durante o regime militar no Brasil. A moça, esse fantasma que ronda a narrativa, é o centro temático da maioria dos capítulos, compostos por emaranhados de fragmentos de informações imprecisas sobre o que pode ter acontecido a ela. O pai da moça, K., empenha todas as suas forças para tentar investigar o que a repressão pode ter feito à sua filha. De modo semelhante, Alice: não mais que de repente apresenta como tema a morte misteriosa de uma professora de física dentro da USP. O 
cenário não é mais o Brasil da ditadura militar, mas os anos 1990 e uma universidade que vive o esfacelamento da reflexão crítica, herança do regime repressivo. O fantasma que ronda esta narrativa é Alice, que, antes de morrer, deixou, em uma folha escrita com seu sangue, a letra P. A investigação em torno deste crime é o foco do romance, que vai contar com um detetive metódico e viciado em ficção policial chamado Magno, um professor cassado pela ditadura que também colabora com a investigação, vários suspeitos e uma severa crítica à vida dentro da academia.

A estrutura do romance de Kucinski se enquadra no que se costuma denominar como romance de detetive ou romance de enigma. De acordo com Reimão (1983, p.8), este é o tipo mais divulgado de narrativa policial, cujo exemplo mais expressivo é o próprio criador do gênero, Edgar Allan Poe. Neste tipo de narrativa, parte-se de um enigma e busca-se transformá-lo em um não-enigma, isto é, há um mistério em torno de um crime, um evento estranho, que fez uma vítima e o objetivo do detetive é descobrir as explicações para o que parece ter perturbado a normalidade das coisas.

Na concepção de Flávio García (2007, p.20), o insólito não decorre da ordem natural das coisas, mas daquilo que não é característico ou próprio de acontecer, que foge do usual ou do previsto, que é fora do comum. Sendo assim, o insólito se faz presente em diversos gêneros, entre eles a narrativa criminal que é o foco deste estudo. Como parte-se de um evento extraordinário que, ao final, é elucidado, o insólito estaria relacionado a uma categoria que Tzvetan Todorov (2013, p.156) chamou de estranho. O crime instigante causa hesitação porque parece inexplicável já 
que desafia a realidade, mas a investigação vai resultar em uma explicação lógica, ancorada no real. Não é preciso admitir novas leis da natureza pelas quais o acontecimento pode ser explicado. A realidade permanece intacta depois de esclarecido o caso, fazendo com que a obra seja pertencente ao gênero do estranho. O insólito, enquanto efeito estético no romance Alice, é movido por acontecimentos inusitados, sem características sobrenaturais, apenas por ocorrências que fogem ao padrão, que ameaçam nossa percepção do que é familiar, para nos surpreender com a posterior explicação desses eventos aparentemente inexplicáveis. Assim, a investigação de um crime atípico no espaço da universidade ganha uma atmosfera confusa, provocando situações inquietantes.

\section{A INVESTIGAÇÃO}

O policial investigador do livro de B. Kucinski chama-se Magno da Silva Pereira, nome que denota importância e grandiosidade, contrastando ironicamente com dois sobrenomes comuns no Brasil. Todavia, a personalidade deste policial se afasta muito do que consideramos ser comum na polícia brasileira. O personagem é caracterizado pela elegância ao se vestir e por seu andar resoluto de autoridade: "Lembra um advogado ilustre ou um diretor de banco, não um delegado de polícia" (KUCINSKI, 2014, p.142). É um delegado experiente, formado em direito, cuja inusitada descrição parece chistosa à medida em que o autor mescla a imagem de um investigador sério e eficiente com um Buda pensativo de terno escuro:

Seu rosto cheio e a testa larga lembrariam um Buda pensativo, não fossem as mechas onduladas 
de cabelos negros penteadas para trás. Um rosto que amadureceu sem envelhecer. Dá impressão de candura, mas nada escapa a seus olhos miúdos e penetrantes. (KUCINSKI, 2014, p.19)

Metódico, viciado em cinema e em novelas policiais, animouse ao saber que a morte da professora no campus da USP não parecia ter causas naturais. Isto porque, em trinta anos como policial, só viu aparecerem na delegacia crimes grosseiros, como brigas de casal e assaltos, "Nada a exigir um Sherlock Holmes" (KUCINSKI, 2014, p.19).

Como agora tinha um mistério sobre um crime de assassinato para solucionar em suas mãos, à altura dos crimes desvendados pelo clássico personagem Sherlock Holmes, Magno passa a se portar como um detetive clássico dos romances policiais: registra mentalmente a configuração espacial do ambiente em que ocorreu o crime, repara com atenção nos objetos fora do lugar na sala da professora, levanta a hipótese de envenenamento por arsênico ou sulfato de tálio, cautelosamente questiona com argúcia as pessoas e observa o uso reiterado da palavra "infortúnio" pelos professores da universidade ao descreverem o ocorrido com Alice.

O método que vai ser usado por Magno para conduzir a investigação nos faz lembrar as narrativas criminais estrangeiras, reiteradas ora pelo próprio delegado, ora pelo narrador, e algumas vezes por outros personagens. É o caso do subdelegado Souza, ajudante de Magno, personagem que nos remete a Watson, companheiro nos casos de Sherlock Holmes. Magno, em diversos momentos, dita tarefas para Souza cumprir, como levantamento de antecedentes, interrogatórios, etc. Não cabe ao subdelegado 
investigar os crimes, mas apenas ajudar recolhendo informações úteis para que Magno seja capaz de elucidar o mistério. E é na voz de Souza que o autor expõe o estranhamento causado pela atitude de um delegado da polícia brasileira tão diferente dos demais:

Souza nunca tinha visto uma investigação assim. Parece filme americano, pensa.

- Aqui é Brasil, Magno, não é Miami.

-E daí?

- Daí que é só dar uma dura no suspeito, e ele entrega os comparsas, a muamba, a quadrilha toda. Não tem erro. (KUCINSKI, 2014, p.38)

A violência é a marca do sistema policial no Brasil. Ver na ficção personagens que representam policiais agindo de forma diferente nos causa espanto. Apesar da consciência de estarmos diante de uma obra ficcional, o narrador parece interessado a todo momento em localizar os acontecimentos no tempo e no espaço, fazendo com que seja incoerente apresentar uma polícia tão parecida com a dos filmes internacionais e tão diferente da nossa. O leitor começa a suspeitar se o autor vai optar por levar a narrativa suspendendo a realidade da polícia brasileira para se apegar aos moldes da narrativa investigativa clássica. E Souza parece ler os pensamentos dos leitores ao questionar o investigador sobre o método. A explicação que vem em seguida nos faz reconhecer que a atitude diferenciada de Magno naquele caso tem relação direta com o nível dos suspeitos do crime:

- Dar uma dura em quem, Souza, se ainda não tem suspeito? E que tal dar uma dura num professor da USP ou num americano? 
- É, não pensei... É o primeiro caso com pele fina nesta merda de delegacia. (KUCINSKI, 2014, p.39)

O método investigativo clássico da polícia brasileira - dar uma dura no suspeito - somente se aplica aos crimes comuns, ou melhor, ao estereótipo de criminosos comuns no país: o pobre, o negro, o favelado. A um professor da USP ou a um norte americano, este método não se aplica. Quando Magno precisa colher o depoimento da professora Bárbara, acusada de ameaçar Alice através de bilhetes deixados em seu escaninho, por ciúmes do exnamorado, fica clara a diferença entre o tratamento destinado à classe alta e às demais quando há a suspeita de algum crime: "[...] É um problema interrogar gente da classe alta. Nenhum delegado sabe fazer isso. Interrogar pele grossa é fácil. Se for bandido, é só dar umas porradas, como faz o Souza; povão, é só dar uns berros. O pior é que funciona" (KUCINSKI, 2014, p.152).

Dessa forma, a crítica feita pela narrativa à diferença de tratamento da polícia entre supostos níveis de criminosos tenta justificar o modo como Magno irá conduzir a investigação, influenciado pela criminalística americana.

É importante notar, entretanto, que há todo um cuidado por parte de Magno para que sua fascinação pela criminalística americana seja útil à investigação se adequada à realidade brasileira. Quando o delegado vai até Jundiaí, na chácara do tio Nakamura para investigar se o motivo do crime poderia ser familiar, vemolo fazendo isso. Seus anos de experiência na polícia, seu gosto por filmes e romances policiais e seu raciocínio dedutivo fazem a ponte entre o que poderia ser suspeito em uma investigação clássica à la Sherlock Holmes e o mais provável que seja no Brasil: 
É preciso descobrir o móvel do crime, raciocina Magno. Cobiça é o mais comum. Os americanos matam pelo dinheiro do seguro de vida, como a gente vê nos filmes. No Brasil, não é comum fazer esse seguro, mas matam pela herança. Magno já lidara com crimes horríveis motivados por dinheiro. (KUCINSKI, 2014, p.68)

Um dos mistérios centrais da narrativa é o fato de que a xícara de café encontrada no local do crime e o próprio café não apresentavam vestígios de veneno. Mesmo assim, a hipótese mais plausível era a morte por envenenamento, o que fez Magno perceber que talvez o veneno tenha sido ingerido ao longo do tempo e que a vítima tenha morrido aos poucos. Aqui, o gosto pela ficção também influenciará Magno, pois ele passa a desconfiar da universidade como espaço aparentemente tranquilo que esconde conflitos que poderiam ter motivado o crime de assassinato da professora Alice. Lembra que George Orwell associou esse método camuflado de morte quase natural a uma sociedade estagnada, sem conflitos sociais agudos. Lembra também que Simenon situa seus crimes em uma Paris que parece tranquila, mas que camufla um universo de incestos, adultérios e negociatas: "[...] Se o móvel do crime não está na família, pensa Magno, estaria na universidade? Seria a universidade essa sociedade estagnada e decadente? Será que sob seu manto de cultura e saber acadêmico esconde-se um emaranhado de conflitos e negócios escusos?" (KUCINSKI, 2014, p.73).

O laudo do IML da autópsia de Alice confirmou a hipótese do envenenamento, como Magno desconfiava, entretanto, o problema que se impunha era que não conseguiram identificar o veneno usado. Magno desconfiava de tálio e vai recorrer à 
literatura policial como fonte de pesquisa. O policial busca o livro Cavalo amarelo, de Agatha Christie, para nortear sua investigação:

Magno relê o capítulo do romance de Agatha Christie que descreve o envenenamento por tálio. [...] Os sintomas de envenenamento narrados no romance batem com o que ele tinha estudado na ficha, mas trazem mais uma divergência em relação ao caso de Alice: ela não se queixou a ninguém de dormência ou formigamento nas mãos, os primeiros efeitos do contato com o tálio, segundo Agatha Christie, que nos aspectos técnicos de seus livros costuma ser rigorosa. (KUCINSKI, 2014, p.113)

E é no capítulo 19 que a narrativa regride para bem antes do momento do crime de assassinato da professora na USP. Nesta parte do livro, é relatado o sonho de criança de Magno: prender bandidos e desvendar crimes misteriosos. Quanto à primeira parte do sonho, conseguiu realizar tornando-se policial. Mas logo se decepcionou, pois certa vez foi convocado para prender estudantes durante a ditadura que estavam farreando além da conta, mas Magno sabia que aqueles não eram bandidos, eram jovens como seus sobrinhos. Desde este episódio, passou a refletir criticamente sobre o ofício de policial e a se dedicar cada vez mais ao estudo da criminalística e menos às ocorrências:

Hoje ele nem gosta de ser policial. Tem nojo de coisas que vê nas delegacias. Sabe de colegas que matam a esmo ou cometem chacinas de inocentes para vingar um colega morto por bandidos. Como retaliação. Como os nazistas que durante a ocupação da Polônia executavam dez escolhidos a esmo para cada alemão morto. (KUCINSKI, 2014, p.140) 
Assim, o leitor vai conhecendo o caráter do delegado que procurou distância da repressão durante os anos de chumbo e que muito se interessava por investigação criminal. Talvez por essa razão as ficções investigativas o atraiam tanto e Magno tenha atitudes tão distintas das da maioria dos policiais. Uma dessas atitudes fez com que ele conhecesse o professor Zimmerwald, cientista famoso por ter calculado a massa de certas estrelas, comunista cassado, expulso da USP que, atualmente, se dedica à crítica de arte. Durante o regime militar, no DOPS, Magno viu um coronel exibindo um jornal com a foto do cientista e se gabando de que daria uma dura nele. Conseguiu o telefone do professor e o aconselhou a dar uma arrumada nas gavetas e sair de São Paulo por um tempo. Fez o mesmo com outras três pessoas:

\begin{abstract}
Magno é de uma família de estivadores. $\mathrm{O}$ tio de quem ele mais gosta havia sido dirigente sindical e uma vez contou a ele uma história comprida sobre a diferença entre o certo e o errado. Magno só tinha dez anos. Os detalhes da história, ele esqueceu, mas o básico do que o tio quis dizer ficou.(KUCINSKI, 2014, p.142)
\end{abstract}

Essa distinção, ensinada pelo tio, entre o certo e o errado marca a ética empregada por Magno em seu ofício como policial. O que nos causa estranhamento é que, mesmo estando em um ambiente de corrupção, traição e violência, o delegado é fiel ao que acredita ser o certo e não se corrompe: "Magno não bate, embora não falte vontade. Controla-se. A voz engrossa às vezes, mas só para homem que espanca mulher. Lembra sempre do tio portuário e da história do certo e do errado." (KUCINSKI, 2014, p.152).

Na tentativa de elucidar a misteriosa tragédia que se deu com sua querida amiga Alice, o cientista salvo pelo telefonema de Magno 
durante a ditadura, o professor Zimmerwald, com a ajuda do orientando da professora, Rogério, empreendeu suas próprias investigações sobre o crime. A exemplo de alguns detetives de romances policiais, como é o caso de Dupin, personagem criado por Edgar Allan Poe, uma máquina de raciocínio que conhece os fatos por ouvir dizer, sem que seja necessário o contato com o local em que o fato ocorreu, assim também acontece com o professor Zimmerwald, que sofre de fotofobia, dorme de dia, trabalha de noite e pouco sai de seu apartamento. A escuridão e a reclusão não são obstáculos para que Dupin e Zimmerwald enxerguem os fatos com clareza. No conto A carta roubada, Dupin nos mostra que a escuridão é grande aliada para solucionar casos muito complicados: "Se é ponto que queira reflexão - observou Dupin, abstendo-se de acender o pavio - melhor será que o examinemos no escuro." (POE, 2008, p.48).

Dessa forma, durante a narrativa, ao mesmo tempo em que Magno, com o auxílio de Souza, começa a investigar o crime, o professor Zimmerwald, metódico como o policial, com o auxílio de Rogério, faz o mesmo, buscando objetos da cena do crime que foram desprezados pela polícia, investigando as últimas pesquisas feitas pela professora em seu computador e indo até a casa de Alice para analisar cartas ameaçadoras enviadas a ela por alguma ex-namorada de Percival, professor com quem estava se relacionando antes de morrer. 0 cientista assume também o papel de detetive para tentar ir além da polícia, a exemplo dos detetives clássicos dos primeiros romances de enigma, como Dupin, que formula suas teorias baseado nos detalhes ignorados pelos policiais. 
Quando Zimmerwald soube da morte de Alice, logo desconfiou do americano Peter Gallup, físico nuclear de Princeton que queria levar a professora para os Estados Unidos. A pesquisa que Alice estava finalizando, antes de sua morte, objetivava desenvolver algoritmos que reduziriam à metade o tempo gasto pelos americanos para calcular reações nucleares. Para o professor, Peter poderia ter se frustrado com a rejeição do convite feito à Alice para ir aos Estados Unidos e ter visto a professora como uma ameaça, já que os americanos até hoje controlam nosso programa nuclear. Corroborando a visão brasileira de que a polícia daqui é ineficaz e que não tem condições de elucidar sozinha um possível caso de conspiração internacional, Zimmerwald resolveu empreender sua própria investigação. Porém, sabendo que o delegado que estava à frente do caso era Magno, resolveu retribuir a gentileza de 20 anos atrás, pois o caráter de Magno, como a narrativa já nos esclareceu anteriormente, não é como o dos outros policiais, ele é um delegado incomum. Assim, Zimmerwald abre uma exceção e, diferenciando-se do clássico detetive Dupin, que tomava como desprezível o chefe de polícia parisiense em A carta roubada, decide trabalhar no caso com o policial Magno.

Dessa forma, as duas investigações se cruzam e o conhecimento de criminalística de Magno unido ao conhecimento científico de Zimmerwald vão culminar em uma parceria eficiente, fazendo com que o delegado se remeta a outro caso ficcional de parceria acidentada e improvável: o detetive Valentin e o padre Brown dos contos de Chesterton.

A estratégia de comparar a ajuda de um cientista à ajuda de um padre é curiosa, tendo em vista que é clássica a oposição entre 
a razão, característica da ciência, e a fé, característica da religião. O padre Brown se destaca por ser capaz de conhecer e entender a alma das pessoas, a natureza humana. Os casos que o sacerdote ajuda a investigar são casos em que a lógica e a ciência não são capazes de elucidar todos os mistérios. O padre Brown é o oposto do detetive científico: seu método não consiste em examinar vestígios, mas em compreender as causas psicológicas que levaram o criminoso a cometer o crime. Ao contrário disso, o professor Zimmerwald dispõe de seu profundo conhecimento científico para desvendar a tragédia ocorrida com a professora.

Entretanto, cabe ressaltar um aspecto que o narrador das histórias protagonizadas por padre Brown e Valentin tem em comum com a novela de Kucinski: ele é preferencialmente heterodiegético. Os primeiros romances de enigma, a exemplo de Edgar Allan Poe nos textos em que Dupin aparece, apresentam narrador homodiegético, ou seja, em primeira pessoa, que geralmente são os memorialistas dos detetives. Este fato nos conduz a um artifício bastante utilizado na ficção policial para manter o suspense da trama: não revelar o raciocínio do detetive diretamente ao leitor. Geralmente, o narrador era quem acompanhava o detetive em suas investigações e sua forma de narrar não escondia a admiração pela astúcia do investigador; então, era possível dessa forma manter o leitor afastado dos pensamentos do detetive relacionados à resolução do mistério e, ao mesmo tempo, ciente de tudo o que ocorria ao redor da investigação. Chesterton e Kucinski adotam o narrador heterodiegético para suas narrativas criminais. O efeito resultante dessa estratégia é uma narrativa menos marcada por impressões 
e sentimentos do narrador. Segundo Daniel Silva, o narrador em Chesterton é quase transparente, "de tal modo que, feitas as intervenções do narrador, muito contos se desenrolam com seguidas páginas de diálogos entre os personagens, pontualmente quebrados por descrições das ações que se desenrolam" (SILVA, 2017, p.62). Assim também acontece em Alice, que tem o mistério central revelado para o leitor através das falas dos personagens que se unem para elucidar o crime.

O que vai dar o tom de absurdo à situação é que a união de um policial com um comunista cassado pela ditadura não é um evento peculiar, nem presumível, nem provável. O telefonema que Magno deu para Zimmerwald durante a ditadura pode ter salvado sua vida e já consiste em um episódio incomum: um policial que convive com outros militares dentro do DOPS intercede pela vida de um comunista. Durante a narrativa, vimos que quando os dois homens firmam sua parceria na investigação do caso Alice, acabam se tornando íntimos, a ponto de Magno chamar o professor pelo primeiro nome. E em uma específica cena irreverente em que os dois interagem, é possível notar claramente a presença do elemento insólito entre eles. Quando Zimmerwald propõe a Magno levar os tecidos das vísceras de Alice e os cacos de sua xícara de café a um laboratório em São José dos Campos que possui um detector de partículas alfa, o delegado resolve fumar para ponderar. Neste momento, o cientista oferece a ele um charuto cubano: "- Prove um Monte Cristo, delegado. Esse charuto é só para chefes de Estado e amigos do Fidel. É uma das poucas vantagens de ser comunista" (KUCINSKI, 2014, p.150). 0 que pode parecer inacreditável para o leitor é que, em clima de 
descontração, Magno e Zimmerwald fumam o charuto cubano sorrindo em cumplicidade.

Quando, enfim, a dupla consegue desvendar o mistério e descobre o autor do crime, quem recorre à narrativa criminal desta vez é o professor Zimmerwald para pensar em um modo de expor o criminoso. Pensando em agir como Nero Wolfe, personagem de Rex Stout, o cientista planeja convocar os suspeitos para uma reunião em seu apartamento, inclusive seu adversário, o inspetor Cramer, para revelar o culpado. Porém, a essa comparação Magno resiste em concordar, pois, apesar de compartilhar a admiração por Nero Wolfe, sabe que o personagem Cramer foi criado para ridicularizar a mentalidade policial e não se considerava também um inimigo do cientista. A ética adotada por Magno durante toda a investigação, o comprometimento em defender o que é certo, não faz do delegado um personagem policial menor, como é comum em outras narrativas. Ele não é um policial decadente e imoral, alvo de chacota no enredo. Pelo contrário, influenciado por uma história que ouviu quando criança sobre a diferença entre o certo e o errado e por filmes e livros de ficção detetivesca, Magno é a representação de uma concepção diferente da disseminada pelo senso comum sobre a instituição policial.

\section{O CRIME}

A ficção detetivesca gira em torno da descoberta de um enigma. No caso do romance Alice, o mistério centraliza-se na análise de três pontos principais: Quem? Como? Por quê?

A faxineira Marileuza é a personagem que chega primeiro na cena do crime. A descrição da cena da faxineira chegando na USP 
quase se confunde com uma ambientação propriamente gótica, um locus horribilis:

No inverno, as noites no campus são mais longas e opacas. Ainda não clareara por completo quando Marileuza apeou do circular, nos altos da antiga fazenda em que se instalara a Universidade de São Paulo, para sua faina diária no Instituto de Ciências Físicas. Na planície distante, uma névoa branca e densa cobria como mortalha o arvoredo e os edifícios mais baixos. (KUCINSKI, 2014, p.13)

Em uma manhã ainda escura por causa do inverno, em uma deserta e antiga fazenda onde fica a USP, a névoa parece cobrir como mortalha árvores e algumas construções. Este local sinistro que inspira medo é a porta de entrada do romance que guarda um enigma. A sala destrancada da professora Alice tão cedo é indício de desconfiança para Marileuza: "Teve o estranho pressentimento de que aquele não seria um dia como os outros" (KUCINSKI, 2014, p.14). A faxineira então se aproxima e vê o cadáver da professora caído sobre a escrivaninha.

A morte dentro do campus da USP constitui o primeiro elemento que vai caracterizar como insólita a tragédia da professora, anunciada pelo próprio título do primeiro capítulo: $A$ morte insólita. O episódio da morte dentro daquele lugar já pode ser tomado como insólito se, de acordo com García (2007, p.20), é um evento que foge do usual. Isto porque, como veremos no decorrer da narrativa, o único crime comum na universidade parece ser o roubo de equipamentos. É função do vigia noturno impedir esse tipo de crime: "[...] minha função é impedir roubo de equipamento, não é vigiar professor" (KUCINSKI, 2014, p.16). E o próprio delegado 
Magno já esteve no local anteriormente para investigar esse crime que não acontece há algum tempo: "Magno sente-se desorientado entre tantas edificações novas erguidas depois que esteve no Instituto para investigar um roubo de equipamentos" (2014, p.24).

Todos começaram a desconfiar de AVC, mas o detetive Magno não tinha dúvidas de que não se tratava de um caso de morte natural, mas sim de envenenamento por arsênico ou sulfato de tálio, já que notou que havia desprendimento de cabelos, sangue, gavetas fora do lugar e telefone fora do gancho. Se a possibilidade de uma morte dentro do campus já não era habitual, a hipótese de uma morte por envenenamento torna-se chocante. Ainda mais quando a própria morta tenta deixar uma pista com o dedo molhado em seu sangue: em um papel, Alice, antes de morrer, escreveu a letra P.

Quando o legista chega ao local do crime para examinar a cena, o mistério do envenenamento se agrava, pois os cabelos de Alice se soltam como por ação do arsênico, mas as unhas não têm estrias; o que o leva a pensar na hipótese de envenenamento por tálio. O problema é que o tálio escurece os pelos e isso não ocorreu com a professora. As suspeitas de Magno sobre o veneno que poderia ter sido usado para matar Alice não se confirmam.

Muitos são os mistérios: a pesquisa suspeita que estava deixando Alice excitada nos últimos tempos; as tentativas do Petter Gallup de levar a pesquisadora para os Estados Unidos; o mal estar no estômago sentido recentemente; uma suposta briga por herança; a instabilidade na relação com o administrador do Instituto, Bruno, que é responsável pelo café de sua sala; as 
cartas cheias de ameaças de uma ex-namorada do homem com quem estava se relacionando antes de morrer. Isso tudo somado a duas questões centrais: O que envenenou a moça? E o que ela quis sugerir com a letra $\mathrm{P}$ em sua última mensagem? $\mathrm{O}$ exame toxicológico não conseguiu apontar a substância que matou a professora, isto é, foi um caso de veneno excepcional, que não parece não ter deixado rastros. Além disso, o $\mathrm{P}$ feito por ela poderia ser outras letras inconclusas, como um B ou um $\mathrm{R}$, o que faz aumentar a tensão sobre a identidade do assassino, visto que o nome de muitos personagens inseridos na trama tem alguma das iniciais suspeitas.

Durante a narrativa, o locus horribilis do início do livro, a USP, se mostra um universo de intrigas, corrupção, cobiça, vaidade, machismo e mesquinharia em que imperam o poder e o medo. O narrador expõe as relações de interesse entre as pessoas, os troca-trocas que acontecem dentro de um mesmo instituto, as artimanhas usadas para obter um segundo salário de forma desonesta, a divisão em castas dos que trabalham naquele local, os cargos assumidos por pressão de grupos dominantes, as fundações financeiras criadas por institutos para terem autonomia financeira, chefes que forçam a colocação de seus nomes em artigos, entre outros absurdos. 0 modo como a pesquisa científica é incentivada no Brasil também não escapa das críticas do autor. B. Kucinski apresenta ao leitor o incentivo à produtividade pela quantidade de trabalhos de um acadêmico, "como se a ciência fosse linha de montagem" (KUCINSKI, 2014, p.80). E inclui em suas reflexões críticas os truques usados pelos pesquisadores para fraudar esse método, como a imposição de seu nome nos 
trabalhos dos orientandos, a reciprocidade dos acadêmicos ao colocar o nome do outro em seu trabalho, os textos publicados de forma fragmentada em que cada pedaço está numa revista diferente, entre outros.

A ditadura é um tema caro ao autor e, apesar de não ser o assunto principal em Alice, é mencionada como causadora da morte das universidades por conta das cassações aos melhores e mais sérios professores: "[...] Foi a sentença de morte da universidade. Na minha opinião, delegado, esse foi o maior estrago infligido ao nosso pobre país pela ditadura. As gerações seguintes abandonaram a reflexão crítica" (2014, p.83). Mais adiante, remetendo-se a um episódio de seu livro $K_{\text {., }}$ o autor insere uma menção ao caso da demissão de sua irmã desaparecida durante o regime militar pela Congregação do Instituto de Química, que sabia de seu envolvimento com um grupo de oposição ao regime, mas que, mesmo assim, a acusou de abandono de cargo, colaborando com que a moça não fosse reconhecida como uma desaparecida política: "Veja o caso da Congregação de Química, que demitiu, por abandono de cargo, uma professora que eles sabiam que tinha sido sequestrada pelos militares" (2014, p.123).

Em meio às críticas ao universo acadêmico, o livro apresenta o machismo, a podação e a inveja como problemas graves enfrentados por Alice naquele espaço. Isso ocorria principalmente por parte do chefe de departamento Akira, um japonês, assim como a professora, que se sentiu humilhado quando, em um seminário de um orientando, ela resolveu uma equação que ele dizia não ter solução. Depois disso, o Akira perseguiu Alice de todas as formas que pôde, até mesmo publicou como dele uma 
apostila escrita por ela. Mas, nem assim a professora reagiu. Apesar de muito determinada, Alice mantinha a cultura japonesa do orgulho e do respeito à autoridade e aos mais velhos.

Apenas depois de remexer no lixo da sala da Alice é que o mistério do envenenamento começa a ser solucionado. O professor Zimmerwald, com a ajuda de Rogério, analisa os detritos do cesto de lixo e o que mais chama a atenção são os invólucros de chocolate recheado que Alice recebeu de presente de aniversário. A professora talvez tenha comido alguns bombons daqueles muitos dias antes de sua morte e ingeriu mais alguns no dia da tragédia. Assim, se o veneno estava nos bombons, estaria explicado o processo incomum de intoxicação lenta.

Quando o resultado do detector de partículas alfa chega, as suspeitas do professor Zimmerwald se confirmam: a substância usada era o polônio 210. Se o cientista empenhado em desvendar o enigma sem sair de sua casa não ajudasse na investigação analisando as últimas pesquisas de Alice e reconhecendo a ação de radiação graças aos seus estudos no pós-guerra, a polícia não seria capaz de intuir a substância, nem identificá-la com seus aparelhos, e o crime marcado pelo absurdo - por ser um caso claro de envenenamento, mas estranhamente sem veneno - não seria elucidado, tendo em vista que a radiação é uma arma invisível. Enfim, o mistério da letra P na mensagem escrita por Alice foi desvendado: a letra não apontava para uma pessoa, e sim para uma substância, já que a cientista antes de morrer, desconfiava de que estava sendo envenenada.

Tendo resolvido a forma com que o crime se deu, ainda faltava identificar o autor e o motivo para matar a professora. A pessoa 
responsável pela tragédia deveria ser capaz de produzir o polônio 210 e isso não era nada fácil. Mas, dos suspeitos, o único que tinha acesso ao IPEN era o Akira. O professor Zimmerwald, através de seus amigos, conseguiu descobrir o registro de retirada de dois microgramas de polônio 210 pelo chefe de departamento. O método usado por Akira para obter o elemento radioativo o levaria a um crime duplamente perfeito: assassinato e fraude acadêmica. Isto porque, para dar conta de justificar a retirada do elemento, o professor deu entrada em um projeto de pesquisa que menciona o polônio 210 como fonte de emissão radioativa. Assim, poderia ganhar pontos de produtividade - anteriormente criticados pela narrativa - publicando um trabalho com base em pura invenção.

Akira, descrito como um pesquisador fraudulento e medíocre, se supera ao ter planejado o crime como um cientista estuda e planeja uma experiência complexa e delicada: "Concebeu uma arma invisível, tanto no transporte quanto nos vestígios, e um método nunca usado antes, portanto sem registro na criminalística. Foi um inovador na arte do crime. E um lógico, como todo cientista, teórico ou experimental" (KUCINSKI, 2014, p.187).

O provável motivo do assassinato começou com o orgulho ferido do chefe de departamento. Para compensar sua mediocridade no âmbito científico, Akira conseguia verbas e parcerias para a construção de laboratórios, que não foram o bastante para que ele obtivesse reconhecimento no mundo da ciência. Mas o ciclo de laboratórios esgotou-se. E Alice, cansada das repetitivas agressões do chefe, mudou de departamento, fazendo com que ele não pudesse mais descarregar sua raiva, eliminar a humilhação que estava na origem de seus problemas. 
As provas contra Akira são bobas, se comparadas à complexidade do crime cometido: foram encontradas impressões digitais do professor na caixa de bombons e no cartão de feliz aniversário. Parece que ele estudou tanto para chegar a uma arma invisível que se esqueceu da técnica das digitais, o que está em consonância com a segunda epígrafe que o livro apresenta, um trecho de um ensaio de George Orwell, ao delinear o que seria um crime perfeito aos olhos do leitor do News of the world: "Só chegou ao ponto de cometer um crime após um longo conflito de consciência, mas, tendo decidido matar, planejará o assassinato com astúcia e só lhe escapará um pequeno e imprevisto detalhe" (ORWELL, 2011, p.352).

No início da investigação, a arma do crime parecia ser invisível. Depois de identificada, parecia ser impossível chegar ao criminoso, dada a dificuldade de se obter o elemento químico usado para envenenar a professora. Como em alguns casos do detetive Dupin, nos textos de Edgar Allan Poe, embora a situação pareça totalmente incomum, existe uma explicação possível dentro do texto. Como vimos, essas narrativas acabam se enquadrando dentro da categoria denominada por Todorov como estranho. E o efeito estético do insólito na narrativa de Kucinski se manifesta através de uma estratégia textual que Acacio Santos considerou essencial para o sucesso de público das narrativas de Sherlock Holmes: "a invocação do insólito para nos surpreender, com a subsequente redução do estranho, do inexplicável, ao senso comum" (SANTOS, 2010, p.211).

Desvendado o enigma, a narrativa deve chegar ao fim com a punição do criminoso, a representação do mal. E assim é feito, pois Akira vai preso, condenado a trinta anos de prisão. Porém, 
transcorrido um ano da morte de Alice, outra morte insólita ocorre: o suicídio de Akira por harakiri. O medíocre cientista, comparado tantas vezes na narrativa a um samurai que, na ficção, fica desempregado e disfarça este fato agindo com mais arrogância, se aplica a pena de morte perante a desonra pelo crime cometido. $\mathrm{O}$ ritual suicida japonês é reservado aos guerreiros samurais que cortam o abdômen e demonstram sua coragem, autocontrole e determinação. O elemento inesperado incluído no fim da narrativa que instaura uma desestabilização no leitor está na última frase do livro: "Nunca se descobriu como a faca chegou às suas mãos". (KUCINSKI, 2014, p.188). Dessa forma, o elemento insólito está presente como estratégia no desfecho misterioso do livro: a arma usada pelo suicida para tirar a própria vida não é invisível, como a radiação que matou Alice, mas chega até suas mãos sem uma explicação coerente.

\section{CONSIDERAÇÕES FINAIS}

Em seu texto, Tipologia do romance policial, Todorov (2013, p.95) reforça uma posição preconceituosa bastante difundida pela crítica literária ao contrapor literatura e romance policial quando afirma: “O romance policial tem suas normas; fazer 'melhor' do que elas pedem é ao mesmo tempo fazer 'pior': quem quer 'embelezar' o romance policial faz 'literatura', não romance policial.". Sem adentrarmos na discussão sobre o que é literatura e o que pode ser considerado romance policial, é preciso considerar que o gênero policial evoluiu desde o estudo do crítico no início da década de 1970.

Jorge Luiz Marques observa o surgimento de outras três tendências no contexto nacional diferentes das forjadas pelo crítico na obra em questão: 
A primeira diz respeito à incorporação do humor como pièce de resistence nas narrativas, resultando no que poderíamos denominar de "comédia policial"; a segunda expande os limites do gênero para o terreno da crítica social, revelando mazelas do país a partir de uma fabulação que, porém, não perde de vista o investimento nos elementos característicos do romance policial; já o terceiro constitui, na verdade, um subgênero das narrativas das minorias, tão valorizadas nesses tempos pósmodernos, e envereda pela diversidade sexual, resultando no que pode ser considerado "romance policial gay". (2016, p.224)

O romance policial de B. Kucinski apresenta as características da segunda tendência notada por Marques ao tecer considerações sobre o gênero policial na contemporaneidade. Alice é uma narrativa que traça uma séria crítica à decadência da universidade no Brasil. Sob o pretexto de solucionar uma morte misteriosa dentro da USP, o narrador conduz os olhares dos leitores para o absurdo vivido no universo sombrio daquele lugar.

Valendo-se de elementos textuais típicos de uma narrativa de enigma, o autor surpreende ao unir um cientista comunista perseguido pela ditadura a um policial íntegro e sério. E se o local do crime é um ambiente onde se faz ciência, é esta quem vai auxiliar na elucidação do mistério da arma invisível. Tendo descoberto o enigma que abre o livro, nomeado no título como A morte insólita, que foi causada por uma arma incomum, a radiação, o elemento insólito reaparece como enigma final rompendo de forma incoerente as expectativas da realidade: o assassino se mata com uma peixeira que entrou na prisão de forma imperceptível. De acordo com García (2007, p.19), 
entende-se por insólito aquilo que é pouco costumeiro, que pode surpreender o senso comum, que diverge das expectativas dos leitores, dada a sua experienciação da realidade. Considerando então que a classificação de insólito depende da recepção dos leitores em termos de grau de familiaridade na apreensão dos elementos dispostos no romance, tomaremos o misterioso aparecimento da arma do chefe de departamento japonês como uma grande incoerência em relação à nossa realidade e, portanto, consideraremos sua morte como insólita, instaurando novamente um processo de desestabilização na narrativa, mas desta vez sem elucidação.

\section{REFERÊNCIAS}

GARCÍA, Flávio (2007). “O 'insólito' na narrativa ficcional: a questão e os conceitos na teoria dos gêneros literários". In: (Org.). A banalização do insólito: questões de gênero literário - mecanismos de construção narrativa. Rio de Janeiro: Dialogarts. p.11-23.

KUCINSKI, Bernardo (2014). Alice: não mais que de repente. Rio de Janeiro: Rocco. MARQUES, Jorge Luiz (2016). "Um caso em investigação: o gênero policial". In: VIEGAS, Ana Cristina Coutinho; PONTES JR, Geraldo; MARQUES, Jorge Luiz (Orgs.). Configurações da Narrativa Policial. Rio de Janeiro: Dialogarts Publicações. p.221-228.

MASSI, Fernanda (2011). "O detetive e o criminoso dos romances policiais contemporâneos". In: ______. O romance policial do século XXI: manutenção, transgressão e inovação do gênero. São Paulo: Cultura Acadêmica. p. 73-104.

ORWELL, George (2011). "O declínio do assassinato inglês". In: . Como morrem os pobres e outros ensaios. São Paulo: Companhia das Letras. p.352-353. PIGLIA, Ricardo (2004). "Os sujeitos trágicos: literatura e psicanálise". In: . Formas breves. São Paulo: Editora Schwarcz. p.49-60.

POE, Edgar Allan (2008). "A carta roubada”. In: . Histórias extraordinárias.

São Paulo: Companhia das Letras. p. 48-68. 
PORTILHO, Carla de Figueiredo (2009). Detetives ex-cêntricos: um estudo do romance policial produzido nas margens. (Tese - Doutorado em Literatura Comparada). Instituto de Letras, Universidade Federal Fluminense, Niterói. In http://livros01.livrosgratis.com.br/cp106115.pdf Acesso em 12.Jun.2020.

REIMÃO, Sandra Lúcia (1983). O que é o romance policial. São Paulo: Brasiliense. SANTOS, Acacio Luiz (2010). "Perversão e sublimação: as dimensões do insólito, de Sade a Lovecraft". In: GARCÍA, Flavio; PINTO, Marcello de Oliveira; MICHELLI, Regina (Orgs.). Insólito e seu duplo. Rio de Janeiro: Dialogarts Publicações. p.204-213.

SILVA, Daniel Lukan Schimith (2017). Culpado ou inocente: O suspense de Poe, Chesterton e Hitchcock. (Dissertação - Mestrado em Literatura). Instituto de Letras, Universidade de Brasília, Brasília. In https://repositorio.unb.br/ bitstream/10482/31671/1/2017_DanielLukanSchimithSilva.pdf Acesso em 12.Jun.2020.

SILVA, Pedro Puro Sasse da (2019). As narrativas criminais na literatura brasileira. (Tese - Doutorado em Literatura Comparada). Instituto de Letras, Universidade Federal Fluminense, Niterói. In https://app.uff.br/riuff/bitstream/1/10095/1/ SASSE.\%20As\%20narrativas\%20criminais\%20na\%20literatura\%20brasileira\%20 \%28final\%29.pdf Acesso em 12.Jun.2020.

TODOROV, Tzvetan (2013). As estruturas narrativas. São Paulo: Perspectiva. 